\title{
Regulation of protumorigenic pathways by Insulin like growth factor binding protein2 and its association along with $\beta$-catenin in breast cancer lymph node metastasis
}

Priyanka Sehgal ${ }^{1}$, Neeraj Kumar ${ }^{1}$, Varuvar Rajesh Praveen Kumar', Shilpa Patil', Animesh Bhattacharya', Manavalan Vijaya Kumar ${ }^{2,3}$, Geetashree Mukherjee ${ }^{2}$ and Paturu Kondaiah ${ }^{1 *}$

\begin{abstract}
Background: Insulin like growth factor binding proteins modulate the mitogenic and pro survival effects of IGF. Elevated expression of IGFBP2 is associated with progression of tumors that include prostate, ovarian, glioma among others. Though implicated in the progression of breast cancer, the molecular mechanisms involved in IGFBP2 actions are not well defined. This study investigates the molecular targets and biological pathways targeted by IGFBP2 in breast cancer.

Methods: Transcriptome analysis of breast tumor cells (BT474) with stable knockdown of IGFBP2 and breast tumors having differential expression of IGFBP2 by immunohistochemistry was performed using microarray. Differential gene expression was established using R-Bioconductor package. For validation, gene expression was determined by qPCR. Inhibitors of IGF1R and integrin pathway were utilized to study the mechanism of regulation of $\beta$-catenin. Immunohistochemical and immunocytochemical staining was performed on breast tumors and experimental cells, respectively for $\beta$-catenin and IGFBP2 expression.

Results: Knockdown of IGFBP2 resulted in differential expression of 2067 up regulated and 2002 down regulated genes in breast cancer cells. Down regulated genes principally belong to cell cycle, DNA replication, repair, p53 signaling, oxidative phosphorylation, Wnt signaling. Whole genome expression analysis of breast tumors with or without IGFBP2 expression indicated changes in genes belonging to Focal adhesion, Map kinase and Wnt signaling pathways. Interestingly, IGFBP2 knockdown clones showed reduced expression of $\beta$ - catenin compared to control cells which was restored upon IGFBP2 re-expression. The regulation of $\beta$-catenin by IGFBP2 was found to be IGF1R and integrin pathway dependent. Furthermore, IGFBP2 and $\beta$-catenin are co-ordinately overexpressed in breast tumors and correlate with lymph node metastasis.
\end{abstract}

Conclusion: This study highlights regulation of $\beta$-catenin by IGFBP2 in breast cancer cells and most importantly, combined expression of IGFBP2 and $\beta$-catenin is associated with lymph node metastasis of breast tumors.

Keywords: IGFBP2, Breast cancer, Wnt signaling, $\beta$-catenin, Integrin

\footnotetext{
* Correspondence: paturu@mrdg.iisc.ernet.in

'Department of Molecular Reproduction, Development and Genetics, Indian Institute of Science, Bangalore 560012, India

Full list of author information is available at the end of the article
} 


\section{Background}

The Insulin like Growth Factor binding proteins (IGFBP) are a family of six proteins that bind with high affinity to Insulin like growth factors (IGF-I and IGF-II), prolong their half-life in circulation and thereby regulate IGF actions. Insulin like growth factor binding protein 2 (IGFBP2) is the second most abundant IGFBP in circulation and in a context dependent manner it can either inhibit or potentiate the actions of IGF [1], thereby modulating the prosurvival and/or mitogenic effects of IGF. Elevated expression of IGFBP2 has been observed in multiple malignancies, including Glioblastoma multiforme [2-4], ovarian [5,6], pancreatic [7], gastric [8], prostate [9], colon [10], breast [11,12], leukemia [13] and thyroid cancer [14]. In addition, increased expression of IGFBP2 has been correlated with poor prognosis in prostate, glioblastoma and colon cancers [15-18]. It has been reported that IGFBP2 inhibits the IGF dependent proliferation of normal cells while in tumor cells, it promotes proliferation in an IGF1R dependent or independent manner $[19,20]$. Pro proliferative action of IGFBP2 has been reported in prostate, ovarian and colon cancer cells and nontransformed rat osteoblasts [19,21-24]. IGFBP2 expression has also been shown to enhance migration and invasion in glioma, ovarian and bladder cancer cells [3,25-27]. Recent studies in glioma implicate IGFBP2 in the activation of PI3K Akt pathway [28], integrin/ILK/NF-B network which drives glioma progression in mice [29] and binding to integrin $\alpha 5$ [30] that brings about increased migration and invasion. In breast cancer, IGFBP2 over expression has been shown to confer drug resistance [11] and increased expression has been reported to correlate with lymph node metastasis In T1 breast carcinomas [31]. However, mechanisms that govern IGFBP2 actions in breast cancers are poorly understood.

In the present study, to elucidate the cellular pathways influenced by IGFBP2 in breast cancer, gene expression profiling of IGFBP2 knockdown breast cancer cells was compared with the expression profile of IGFBP2 positive breast tumors. Our results highlight regulation of cell cycle and Wnt signaling pathways by IGFBP2. Most significantly, our data shows for the first time that the concomitant over expression of IGFBP2 and $\beta$-catenin in breast cancer is associated with increased incidence of lymph node metastasis.

\section{Results}

IGFBP2 perturbation by shRNA alters gene expression profile in breast cancer cells

In view of the pro-tumorigenic actions of IGFBP2 reported in several cancers including breast tumors, we decided to delineate the molecular mechanism of IGFBP2 actions in breast cancers. Initially, stable sub lines of breast tumor cell line BT474 with knockdown of
IGFBP2 were generated. Among several clones, two of the clones ( $\mathrm{C} 5$ and $\mathrm{C} 12)$ that showed considerable knock down of IGFBP2 (Figure 1a) were selected for further studies. Transcriptome analysis of the IGFBP2 knock down cells using Agilent whole human genome $4 \times 44 \mathrm{~K}$ arrays was performed against control cells (vector transfected). Data analysis revealed significant regulation of 4069 probes in both the clones compared to control cells. Among these, 2067 probes showed up regulation while 2002 probes showed down regulation (Additional file 1: Table S1). Hierarchical cluster revealed similar expression pattern of regulated genes in both the clones (Figure 1b). The list of top 25 up and down regulated genes is shown in Table 1 . The differentially regulated genes were subjected to pathway enrichment analysis using GSEA (Table 2). This analysis revealed enrichment of down regulated genes belonging to cell cycle, DNA replication, repair, p53 signaling, oxidative phosphorylation, Wnt signaling, etc. qPCR analysis of some genes validated differential expression seen in microarray data (Figure 1c). Over expression of IGFBP2 in the knockdown cells resulted in up regulation of IGF1R, IGF2, TOP2A, p53, CCND1 and FOXM1 genes which were down regulated upon IGFBP2 knockdown (Additional file 2: Figure S1) suggesting the specificity of the regulation of these genes by IGFBP2. Hence, perturbation of IGFBP2 results in differential expression of several genes and pathways.

\section{Differential expression of genes between tumors staining positive or negative for IGFBP2}

In order to determine, whether expression of IGFBP2 regulated genes as revealed by IGFBP2 perturbation is also altered in tumors, we studied the gene expression patterns in tumors based on IGFBP2 expression. We selected 12 IGFBP2 positive and 7 IGFBP2 negative tumor RNAs for microarray expression analysis using Agilent whole human genome $4 \times 44 \mathrm{~K}$ arrays. Comparison of gene expression profiles between IGFBP2 positive and negative tumors revealed 3460 probes as significantly differentially regulated. Among them, 1635 probes were up regulated and 1825 probes were found to be down regulated in IGFBP2 positive tumors compared to IGFBP2 negative tumors (Additional file 3: Table S2). List of top 25 up or down regulated genes are shown in Table 3. To identify enriched pathways associated with differentially expressed genes, Gene set enrichment analysis (GSEA) was carried out. The genes up regulated in IGFBP2 positive tumor samples showed significant enrichment in Focal adhesion, MAPK signaling pathway, apoptosis, Chemokine signaling, cytokine-cytokine receptor interaction and ECM receptor interaction and Wnt signaling pathway (Table 4). Hierarchical cluster (Euclidean distance method) of $\log 2$ transformed differentially expressed genes between IGFBP2 positive and negative tumors revealed 


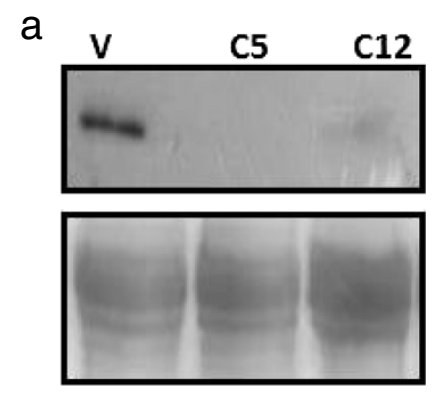

\section{IGFBP2}

b

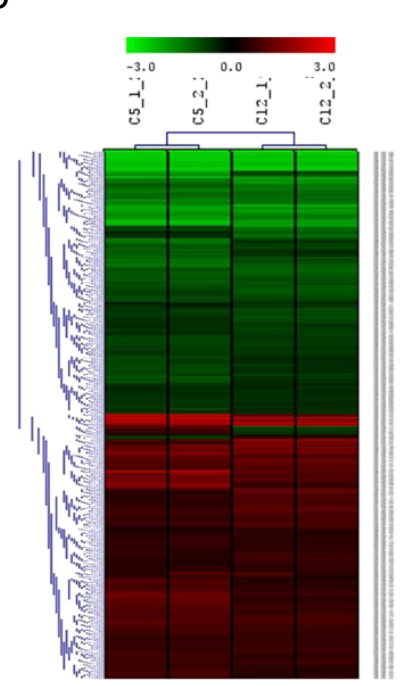

C

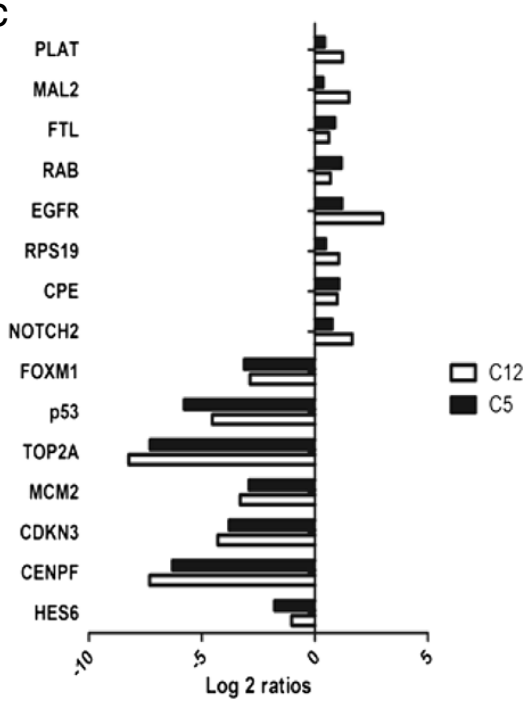

Figure 1 IGFBP2 regulated genes in BT474 breast cancer cells. a) Western blot analysis of IGFBP2 in the supernatant of IGFBP2 knockdown clones C5 and C12 and control cells. Lower panel is ponceau stained membrane shown as loading control. b) Hierarchical cluster of differentially expressed genes in IGFBP2 knockdown BT474 cells versus control cells. Differentially regulated genes were clustered using MeV software. The dendrogram on the left shows different clusters of genes segregated according to the pattern of regulation. Red and green indicate high and low expression of genes respectively. Black indicates no regulation. c) Validation of selected genes by qPCR. Bar graphs of differentially regulated genes in IGFBP2 Knockdown BT474 clones versus control cells. The graphs represent the fold change over control after normalization with the expression of RPL35a.

two major clusters consisting of predominantly either IGFBP2 positive or negative tumors. However, in one cluster, there is a sub cluster representing exclusively IGFBP2 positive tumors (Figure 2a). Microarray results were validated on few genes by qPCR. As shown in Figure 2b, qPCR revealed that CCND1(Cyclin D1), CDC42, GATA 3, SYT13 and SFRP2 and TMEM49 as up regulated in IGFBP2 positive tumors while IGFBP2, NR4A2 and SFRP2 were down regulated in IGFBP2 negative tumors. In addition, since Wnt pathway genes were significantly regulated in IGFBP2 knock down cells, we studied the expression of Wnt target genes in IGFBP2 positive and negative breast tumors. The Wnt target genes CCND1, SFRP2 (Figure 2b) MCAM, SP5 and IGF1 (Additional file 4: Figure S2) were found to be differentially expressed between IGFBP2 positive and negative tumors. Taken together, the data from the IGFBP2 knockdown cells and IGFBP2 positive breast tumors suggest a positive correlation of IGFBP2 with pro-tumorigenic pathways including Wnt pathway in breast cancer.

\section{Common genes differentially expressed in breast tumors} and cell lines based on IGFBP2 expression

In the previous experiments, we identified genes differentially expressed in breast tumors and breast cancer cells lines based on IGFBP2 expression. In order to identify the genes commonly regulated by IGFBP2 in cell lines and tumors, we compared the gene expression profiles of IGFBP2 positive versus negative tumors and IGFBP2 knockdown breast cancer cells. 654 probes were found to be common among IGFBP2 regulated genes in tumors and cell line. Among these 412 probes were down regulated in IGFBP2 positive tumors and up regulated upon IGFBP2 knockdown while 242 probes were up regulated in IGFBP2 positive tumors and down regulated upon IGFBP2 knockdown (Additional file 5: Table S3). Some genes that are 
Table 1 List of top 50 differentially regulated genes $(p<0.05)$ in IGFBP2 knockdown clones

\begin{tabular}{|c|c|c|c|c|}
\hline \multirow[t]{2}{*}{ Probe } & \multirow[t]{2}{*}{ Gene symbol } & \multirow[t]{2}{*}{ Accession no. } & \multicolumn{2}{|c|}{$\begin{array}{l}\text { LOG2 ratios IGFBP2 } \\
\text { (shRNA/scrambled) }\end{array}$} \\
\hline & & & C5 & $\mathrm{C} 12$ \\
\hline A_23_P70007 & HMMR & NM_012484 & -6.1994 & -6.3340 \\
\hline A_23_P115872 & CEP55 & NM_018131 & -5.5493 & -5.7555 \\
\hline A_23_P155815 & HCAP-G & NM_022346 & -5.9516 & -5.6434 \\
\hline A_23_P49878 & FAM64A & NM_019013 & -5.3231 & -5.5775 \\
\hline A_23_P401 & CENPF & NM_016343 & -5.6859 & -5.5456 \\
\hline A_24_P297539 & UBE2C & NM_181803 & -6.0374 & -5.5064 \\
\hline A_23_P52017 & ASPM & NM_018136 & -5.6626 & -5.4146 \\
\hline A_23_P118815 & BIRC5 & NM_001012271 & -5.7127 & -5.3579 \\
\hline A_23_P51085 & SPBC25 & NM_020675 & -5.3333 & -5.2314 \\
\hline A_32_P62997 & PBK & NM_018492 & -5.3592 & -5.1651 \\
\hline A_23_P379614 & OIP5 & NM_007280 & -5.4136 & -5.0805 \\
\hline A_23_P138507 & CDC2 & NM_001786 & -5.3918 & -4.9418 \\
\hline A_23_P74349 & CDCA1 & NM_145697 & -5.0628 & -4.7854 \\
\hline A_23_P375 & CDCA8 & NM_018101 & -4.9988 & -4.7055 \\
\hline A_23_P385861 & CDCA2 & NM_152562 & -4.8413 & -4.6523 \\
\hline A_23_P107421 & TK1 & NM_003258 & -5.1628 & -4.6138 \\
\hline A_23_P50108 & KNTC2 & NM_006101 & -4.5643 & -4.6060 \\
\hline A_23_P124417 & BUB1 & NM_004336 & -4.8189 & -4.5874 \\
\hline A_23_P88331 & DLG7 & NM_014750 & -4.8666 & -4.5641 \\
\hline A_23_P118834 & TOP2A & NM_001067 & -4.9585 & -4.5030 \\
\hline A_24_P234196 & RRM2 & NM_001034 & -4.6703 & -4.4466 \\
\hline A_23_P65757 & CCNB2 & NM_004701 & -4.6828 & -4.4265 \\
\hline A_23_P119943 & IGFBP2 & NM_000597 & -2.4765 & -4.4074 \\
\hline A_23_P88731 & RAD51 & NM_002875 & -4.9625 & -4.3833 \\
\hline A_23_P133123 & MND1 & NM_032117 & -4.6389 & -4.3051 \\
\hline A_23_P31407 & AGR2 & NM_006408 & 4.8060 & 4.2255 \\
\hline A_23_P106194 & FOS & NM_005252 & 2.1989 & 4.2063 \\
\hline A_23_P429998 & FOSB & NM_006732 & 1.5980 & 3.8822 \\
\hline A_23_P113952 & AY227436 & AY227436 & 3.4910 & 3.8165 \\
\hline A_23_P500000 & SCEL & NM_144777 & 3.6586 & 3.2728 \\
\hline A_23_P169437 & LCN2 & NM_005564 & 2.5385 & 3.2159 \\
\hline A_23_P380754 & PRSS1 & NM_002769 & 2.3278 & 3.1664 \\
\hline A_23_P29773 & LAMP3 & NM_014398 & 4.2963 & 3.1041 \\
\hline A_23_P5983 & PLTP & NM_006227 & 1.3270 & 2.8955 \\
\hline A_23_P310274 & PRSS2 & NM_002770 & 2.0382 & 2.8886 \\
\hline A_23_P711170 & TRPV6 & NM_018646 & 2.6719 & 2.7426 \\
\hline A_23_P98121 & FXYD4 & NM_173160 & 3.0264 & 2.6979 \\
\hline A_23_P88095 & TBC1D4 & NM_014832 & 0.9759 & 2.6576 \\
\hline A_32_P230828 & GAS5 & NR_002578 & 1.9990 & 2.6280 \\
\hline A_23_P369343 & KLK8 & NM_144505 & 2.0683 & 2.5972 \\
\hline A_23_P18684 & CLGN & NM_004362 & 2.4448 & 2.5689 \\
\hline A_32_P37592 & SCARNA17 & NR_003003 & 1.7724 & 2.5574 \\
\hline
\end{tabular}

Table 1 List of top 50 differentially regulated genes $(\mathbf{p}<\mathbf{0 . 0 5 )}$ in IGFBP2 knockdown clones (Continued)

\begin{tabular}{llcll}
\hline A_23_P22735 & BEX2 & NM_032621 & 3.3099 & 2.5138 \\
A_24_P921446 & EMP1 & BC017854 & 1.1796 & 2.4896 \\
A_23_P121926 & SEPP1 & NM_005410 & 2.7851 & 2.4722 \\
A_23_P34915 & ATF3 & NM_004024 & 3.5213 & 2.4288 \\
A_23_P105803 & FGF9 & NM_002010 & 0.9259 & 2.3751 \\
A_24_P327886 & TCEA3 & NM_003196 & 2.1369 & 2.3522 \\
A_23_P391344 & RASGEF1A & NM_145313 & 3.5570 & 2.3442 \\
A_24_P18190 & HSPA5 & NM_005347 & 2.8335 & 2.3293 \\
\hline
\end{tabular}

differentially regulated in both are shown in Table 5 . Genes such as FBLN1, ID1, FN1, LMO2, DCK, TLR4 which have important roles in tumor progression were up regulated in IGFBP2 positive tumors and were decreased upon IGFBP2 knockdown in breast cancer cells whereas genes such as SRPRB, POPDC3, ARHGEF4, KCNN4, $\mathrm{BC} 11 \mathrm{~A}$ which have negative role in tumorigenesis were down regulated in IGFBP2 positive tumors and were up regulated in IGFBP2 negative cells $(\mathrm{p}<0.05)$. These results indicate that these genes or the pathways associated with these genes could be truly regulated by IGFBP2 in breast cancer. Some of these genes/pathways may have a role in IGFBP2 mediated tumor progression.

KEGG pathway analysis of common differentially regulated genes between IGFBP2 perturbed cells and IGFBP2 positive tumors revealed that the regulated genes belong to Glioma, Oxidative Phosphorylation, Apoptosis, Pathways in cancer and ErbB signaling pathway (Additional file 6: Table S4).Taken together, these data indicate that tumors with IGFBP2 expression phenotype are associated with distinct changes in expression of genes associated with the regulation of cell proliferation and tumorigenicity.

\section{$\beta$-catenin expression is regulated by IGFBP2 in breast cancer cells}

Since the GSEA analysis of differentially expressed genes in both tumors and knockdown cells revealed significant regulation of Wnt signaling pathway, we decided to examine if IGFBP2 regulates Wnt pathway. As $\beta$-catenin is an effector of Wnt pathway we determined $\beta$-catenin expression in IGFBP2 knockdown cells. As shown in Figure 3, knockdown of IGFBP2 in BT474 breast cancer cells substantially decreased the expression of $\beta$-catenin in both the clones $\mathrm{C} 5$ and $\mathrm{C} 12$, suggesting a direct regulation of $\beta$-catenin by IGFBP2. In good correlation, when IGFBP2 expression is restored in the knockdown cells, $\beta$-catenin expression is also restored (Figure 4). These results collectively demonstrate regulation of $\beta$-catenin expression by IGFBP2. 
Table 2 GSEA summary of pathways associated with genes down regulated upon IGFBP2 knockdown

\begin{tabular}{|c|c|c|c|c|}
\hline NAME & SIZE & NOM p-val & FDR q-val & FWER p-val \\
\hline KEGG_CELL_CYCLE & 49 & 0 & 0 & 0 \\
\hline KEGG_DNA_REPLICATION & 28 & 0 & 0 & 0 \\
\hline KEGG_NUCLEOTIDE_EXCISION_REPAIR & 15 & 0 & 0 & 0 \\
\hline KEGG_MISMATCH_REPAIR & 15 & 0 & 0 & 0 \\
\hline KEGG_PATHOGENIC_ESCHERICHIA_COLI_INFECTION & 15 & 0 & $2.19 \mathrm{E}-04$ & 0.001 \\
\hline KEGG_HOMOLOGOUS_RECOMBINATION & 15 & 0 & $1.83 \mathrm{E}-04$ & 0.001 \\
\hline KEGG_PYRIMIDINE_METABOLISM & 21 & 0 & $1.56 \mathrm{E}-04$ & 0.001 \\
\hline KEGG_OXIDATIVE_PHOSPHORYLATION & 19 & 0 & 0.00635 & 0.039 \\
\hline KEGG_PARKINSONS_DISEASE & 21 & 0 & 0.01229 & 0.082 \\
\hline KEGG_PROGESTERONE_MEDIATED_OOCYTE_MATURATION & 17 & 0.006186 & 0.013514 & 0.098 \\
\hline KEGG_SPLICEOSOME & 32 & 0.002012 & 0.01617 & 0.128 \\
\hline KEGG_OOCYTE_MEIOSIS & 30 & 0 & 0.02404 & 0.199 \\
\hline KEGG_P53_SIGNALING_PATHWAY & 26 & 0 & 0.027815 & 0.247 \\
\hline KEGG_HUNTINGTONS_DISEASE & 30 & 0.004098 & 0.032137 & 0.3 \\
\hline KEGG_WNT_SIGNALING_PATHWAY & 21 & 0.045726 & 0.138961 & 0.804 \\
\hline KEGG_PURINE_METABOLISM & 26 & 0.047431 & 0.150692 & 0.844 \\
\hline KEGG_GAP_JUNCTION & 17 & 0.15251 & 0.155502 & 0.877 \\
\hline KEGG_TGF_BETA_SIGNALING_PATHWAY & 15 & 0.393214 & 0.318836 & 0.995 \\
\hline KEGG_SMALL_CELL_LUNG_CANCER & 15 & 0.55144 & 0.400925 & 0.999 \\
\hline KEGG_REGULATION_OF_ACTIN_CYTOSKELETON & 25 & 0.517578 & 0.687552 & 1 \\
\hline KEGG_TIGHT_JUNCTION & 16 & 0.787018 & 0.687305 & 1 \\
\hline KEGG_PATHWAYS_IN_CANCER & 52 & 0.229814 & 0.731651 & 1 \\
\hline KEGG_ALZHEIMERS_DISEASE & 38 & 0.433663 & 0.706543 & 1 \\
\hline
\end{tabular}

NOM $P$ nominal $P$ value.

It has been known that some of the IGFBP2 actions are mediated in part by the activation of IGF1 receptor and also through integrin receptors [20]. Hence, in order to identify the intermediates of IGFBP2 regulation of $\beta$-catenin, we studied the effect of IGF1R inhibitor (PPP, $10 \mu \mathrm{M}$ ) and Focal Adhesion Kinase inhibitor (PP2, $10 \mu \mathrm{M})$ on the regulation of $\beta$-catenin by IGFBP2. As described above, over expression of IGFBP2 in the knockdown clones increased $\beta$-catenin expression and in the presence of IGF1R inhibitor or FAK inhibitor, IGFBP2 induced $\beta$-catenin expression was abolished (Figure 4). Similar results were obtained using MDA-MB-231 cells which lack endogenous IGFBP2 expression (Additional file 7: Figure S3). These results suggest that IGFBP2 regulates $\beta$-catenin expression in an IGF1R and integrin dependent manner.

IGFBP2 and $\beta$-catenin staining together correlates with the lymph node metastasis in human breast cancer Since the previous results showed an increase in $\beta$-catenin expression upon IGFBP2 over expression, we sought to examine the correlation of $\beta$-catenin and IGFBP2 staining in human breast cancer tissues. Towards this we performed IHC on 38 grade III Invasive Ductal Carcinoma tissues for $\beta$-catenin and IGFBP2 expression. A representative staining pattern of IGFBP2 and $\beta$-catenin expression is depicted in Figure 5. It was observed that 27 out of 38 tumors stained positive for IGFBP2. There was a positive correlation between IGFBP2 and $\beta$-catenin expression with 26 out of 27 IGFBP2 positive tumor samples also staining positive for $\beta$-catenin (Table 6). Tissues with $\beta$-catenin expression exhibited a heterogeneous mixture of membranous and cytosolic $\beta$-catenin accumulation. In addition, more lymph node metastasis was observed in patients positive for both IGFBP2 and $\beta$-catenin proteins $(18 / 24,75 \%)$ compared with patients with low levels of both proteins $(1 / 24,4 \%)(\mathrm{p}=0.0006)$.

No significant association of combined expression of IGFBP2 and $\beta$-catenin was observed with ER, PR, Her2 or triple negative receptor status of breast tumors.

\section{Discussion}

Enhanced expression of IGFBP2 is associated with a large number of malignant cancers that include tumors 
Table 3 List of top 50 differentially regulated genes $(p<0.05)$ in IGFBP2 positive versus IGFBP2 negative tumors

\begin{tabular}{|c|c|c|c|}
\hline Probe & Gene name & Accession no. & $\begin{array}{c}\text { Fold change } \\
\text { IGFBP2 +/ IGFBP2- }\end{array}$ \\
\hline
\end{tabular}

$$
\text { A_2 }
$$

A

A_23_P8702

A_24_P137501

A_23_P312300

A_24_P347431

A_23_P372234

A_23_P393099

A_23_P215328

A_23_P213745

A_23_P413641

A_23_P99063

A_23_P75056

A_24_P322771

A_23_P119943

A_23_P161659

A_23_P329768

A_23_P105212

A_23_P95594

A_24_P264943

A_23_P89431

A_32_P133072

A_23_P33196

A_23_P2920

A_23_P22970

A_23_P165778

A_32_P184464

A_23_P328545

A_23_P66137

A_24_P417407

A_23_P53176

A_23_P56197

A_23_P369343

A_24_P236251

A_23_P78248

A_23_P47484

A_23_P10127

A_23_P40108

A_23_P47616

A_23_P50815

A_23_P137173

A_23_P110234

A_23_P216448

A_23_P78980

SCGB2A2

NM_002411

PIP

NM_002652

SFRP2

NM_003013

SCGB2A1

NM_002407

FOXA1

NM_004496

CA12

NM_001218

TFF3

NM_003226

SFRP4

NM_003014

CXCL14

NM_004887

PREX1

NM_020820

LUM

GATA3

NM_002345

TFF1

IGFBP2

NM_001002295

NM_003225

SYT13

NM_000597

NM_020826

NM_014668

THRSP

NM_003251

NAT1

COMP

NM_000662

NM_000095

NM_002982

CCL2

NM_006108

COL5A2

NM_000393

SERPINA3

NM_001085

PIK3R3

NM_003629

$\mathrm{MLPH}$

NM_024101

ROPN1

GABRP

NM_017578

NM_014211

NM_014587

SOX8

ROPN1B

FOLR1

NM_001012337

CRLF1

NM_016725

NM_004750

KLK8

DLK1

KRT23

GLYATL2

NM_144505

NM_003836

NM_015515

NM_145016

SFRP1

NM_003012

COL9A3

NM_001853

FOLH1

NM_004476

NM_020659

TMSL8

NM_021992

CSN1S1

NM_001890

NFIB

NM_005596

NM_014256 IGFBP2 +/ IGFBP2-

4.2566

2.8894

2.4919

2.4797

2.4462

2.3044

2.2590

2.2567

2.1824

2.1719

2.1563

2.0939

2.0888

2.0290

1.9984

1.9528

1.9163

1.9107

1.8625

1.8472

1.8374

1.8357

1.8217

1.7963

1.7915

$-3.5588$

$-2.9846$

$-2.7293$

$-2.5309$

$-2.3657$

$-2.2530$

$-2.2248$

$-2.1531$

$-2.1320$

$-2.1208$

$-2.0505$

$-2.0500$

$-1.8461$

$-1.7817$

$-1.7054$

$-1.6859$

$-1.6243$

$-1.5946$
Table $\mathbf{3}$ List of top $\mathbf{5 0}$ differentially regulated genes $(p<0.05)$ in IGFBP2 positive versus IGFBP2 negative tumors (Continued)

\begin{tabular}{lccc}
\hline A_24_P924484 & K03200 & K03200 & -1.5836 \\
A_32_P157391 & PSMAL & NM_153696 & -1.4833 \\
A_23_P110837 & IRX4 & NM_016358 & -1.4820 \\
A_23_P43157 & MYBL1 & X66087 & -1.4800 \\
A_23_P59960 & CRISPLD1 & NM_031461 & -1.4630 \\
A_23_P422212 & SLC35F3 & NM_173508 & -1.4618 \\
A_23_P37205 & NDRG2 & NM_201535 & -1.4531 \\
\hline
\end{tabular}

of breast, ovarian, glioma and prostate. Primarily known for its growth inhibitory actions in physiological context, IGFBP2 has now been shown to promote growth and tumorigenesis in numerous cancer cells such as glioma, prostate and colon cancers [15-18]. To gain further insights into the role of IGFBP2 in breast cancer, we have attempted to identify the molecular players in IGFBP2 associated tumorigenesis in breast cancer. To elucidate the molecular targets of IGFBP2, we perturbed IGFBP2 expression by shRNA and the differential gene expression was determined using whole genome microarrays. IGFBP2 knockdown resulted in significant changes in the expression of genes associated with cellular proliferation and tumorigenicity. The down regulated genes were found to be associated with several pathways, notably Cell cycle, p53 and Wnt pathways as revealed by GSEA. Comparison of our data with a previous microarray study of IGFBP2 regulated genes in glioma cells [29] revealed an overlap of about $22 \%$ genes with wild type IGFBP2 over expressing cells and $23 \%$ genes with RGE mutant IGFBP2 over expressing cells. Pathway comparisons revealed Cell cycle, p53 signaling, oxidative phosphorylation, nucleotide metabolism and Wnt signaling pathway to be common among the two data sets (Additional file 8: Figure S4). To further validate these results in breast cancer tissues, we performed whole genome expression analysis in 19 breast tumors which were categorized as IGFBP2 positive or negative based on immunohistochemical staining pattern. Compared to IGFBP2 negative tumors, IGFBP2 positive tumors showed increased expression of genes belonging to MAPK signaling, Focal adhesion and Wnt signaling.

IGFBP2 correlation with proliferation has been studied extensively in several tumor cells including in breast cancer cells. The effect of IGFBP2 on proliferation has been shown to be context dependent. In prostate, ovarian, nephroblastoma cells, it has a pro proliferative action [19,21-24]. In contrast IGFBP2 has an antiproliferative effect on HEK, Hs578T [32,33]. Our data on the regulation of different pathways such as MAPK, Cell cycle, Focal adhesion and Wnt corroborate the reported functional 
Table 4 GSEA summary of pathways associated with genes up regulated in IGFBP2 positive tumors

\begin{tabular}{|c|c|c|c|c|}
\hline NAME & SIZE & NOM p-val & FDR q-val & FWER p-val \\
\hline KEGG_MAPK_SIGNALING_PATHWAY & 43 & 0 & 0 & 0 \\
\hline KEGG_LEISHMANIA_INFECTION & 20 & 0 & 0 & 0 \\
\hline KEGG_CYTOKINE_CYTOKINE_RECEPTOR_INTERACTION & 35 & 0 & 0.007717 & 0.013 \\
\hline KEGG_SYSTEMIC_LUPUS_ERYTHEMATOSUS & 19 & 0.001976 & 0.006687 & 0.015 \\
\hline KEGG_T_CELL_RECEPTOR_SIGNALING_PATHWAY & 19 & 0.00211 & 0.016915 & 0.045 \\
\hline KEGG_FOCAL_ADHESION & 30 & 0.007619 & 0.025984 & 0.084 \\
\hline KEGG_COMPLEMENT_AND_COAGULATION_CASCADES & 16 & 0.015968 & 0.023016 & 0.087 \\
\hline KEGG_ECM_RECEPTOR_INTERACTION & 15 & 0.002053 & 0.022288 & 0.096 \\
\hline KEGG_CHEMOKINE_SIGNALING_PATHWAY & 32 & 0.008403 & 0.020502 & 0.1 \\
\hline KEGG_APOPTOSIS & 20 & 0.008584 & 0.018452 & 0.1 \\
\hline KEGG_VIRAL_MYOCARDITIS & 17 & 0.005906 & 0.017723 & 0.105 \\
\hline KEGG_NATURAL_KILLER_CELL_MEDIATED_CYTOTOXICITY & 27 & 0.028902 & 0.037213 & 0.228 \\
\hline KEGG_GNRH_SIGNALING_PATHWAY & 19 & 0.044444 & 0.113272 & 0.563 \\
\hline KEGG_CELL_ADHESION_MOLECULES_CAMS & 26 & 0.095808 & 0.195608 & 0.805 \\
\hline KEGG_ALZHEIMERS_DISEASE & 24 & 0.087302 & 0.183226 & 0.805 \\
\hline KEGG_PATHWAYS_IN_CANCER & 48 & 0.098 & 0.185527 & 0.831 \\
\hline KEGG_AXON_GUIDANCE & 17 & 0.11553 & 0.176978 & 0.834 \\
\hline KEGG_NEUROACTIVE_LIGAND_RECEPTOR_INTERACTION & 24 & 0.136538 & 0.210733 & 0.893 \\
\hline KEGG_DILATED_CARDIOMYOPATHY & 15 & 0.165339 & 0.237117 & 0.925 \\
\hline KEGG_NEUROTROPHIN_SIGNALING_PATHWAY & 19 & 0.168932 & 0.240447 & 0.932 \\
\hline KEGG_MELANOGENESIS & 15 & 0.252033 & 0.367091 & 0.99 \\
\hline KEGG_LYSOSOME & 18 & 0.329389 & 0.436596 & 0.996 \\
\hline KEGG_CALCIUM_SIGNALING_PATHWAY & 19 & 0.367886 & 0.427407 & 0.996 \\
\hline KEGG_WNT_SIGNALING_PATHWAY & 24 & 0.361616 & 0.414545 & 0.996 \\
\hline KEGG_ENDOCYTOSIS & 20 & 0.365503 & 0.423908 & 0.998 \\
\hline KEGG_ANTIGEN_PROCESSING_AND_PRESENTATION & 15 & 0.419958 & 0.454951 & 0.999 \\
\hline KEGG_HUNTINGTONS_DISEASE & 18 & 0.568465 & 0.60777 & 1 \\
\hline KEGG_REGULATION_OF_ACTIN_CYTOSKELETON & 29 & 0.74269 & 0.769736 & 1 \\
\hline KEGG_PURINE_METABOLISM & 20 & 0.933054 & 0.931545 & 1 \\
\hline
\end{tabular}

NOM $P$ nominal $P$ value.

significance of IGFBP2 with respect to its pro proliferative and tumor promoting roles in breast cancer cells.

One of the important and novel findings from this study is the regulation of Wnt signaling pathway genes by IGFBP2. So far, only IGFBP4 has been reported to activate Wnt signaling pathway in renal cell carcinoma [34]. Activation of canonical Wnt signaling promotes tumorigenesis by regulating cell survival, proliferation and invasion of many cancers [35]. In numerous tumors cytoplasmic and/or nuclear accumulation of $\beta$-catenin has been shown to be a strong indicator of aberrant Wnt pathway activation. Elevated cytosolic and nuclear accumulation of $\beta$-catenin has been associated with a variety of malignancies and inversely correlated with patient survival [36-39], Wnt activation leads to stabilization and translocation of $\beta$-catenin from cytoplasm to the nucleus where it associates with T-cell factor (TCF)/ lymphocyte enhancer transcription (LEF) factors to activate target genes that are involved in cell survival, proliferation, and invasion $[40,41]$. In order to establish Wnt pathway activation by IGFBP2, we examined the canonical Wnt signaling target, $\beta$-catenin in IGFBP2 knockdown breast cancer cells. Compared to Vector transfected cells, IGFBP2 knockdown cells showed remarkably decreased levels of $\beta$-catenin. When IGFBP2 was re expressed in the knockdown cells, as expected there was substantial increase in $\beta$-catenin levels indicating that IGFBP2 regulates $\beta$-catenin. Interestingly, inhibition of IGF1R or integrin signaling resulted in the loss of $\beta$-catenin regulation by IGFBP2. These data suggest 


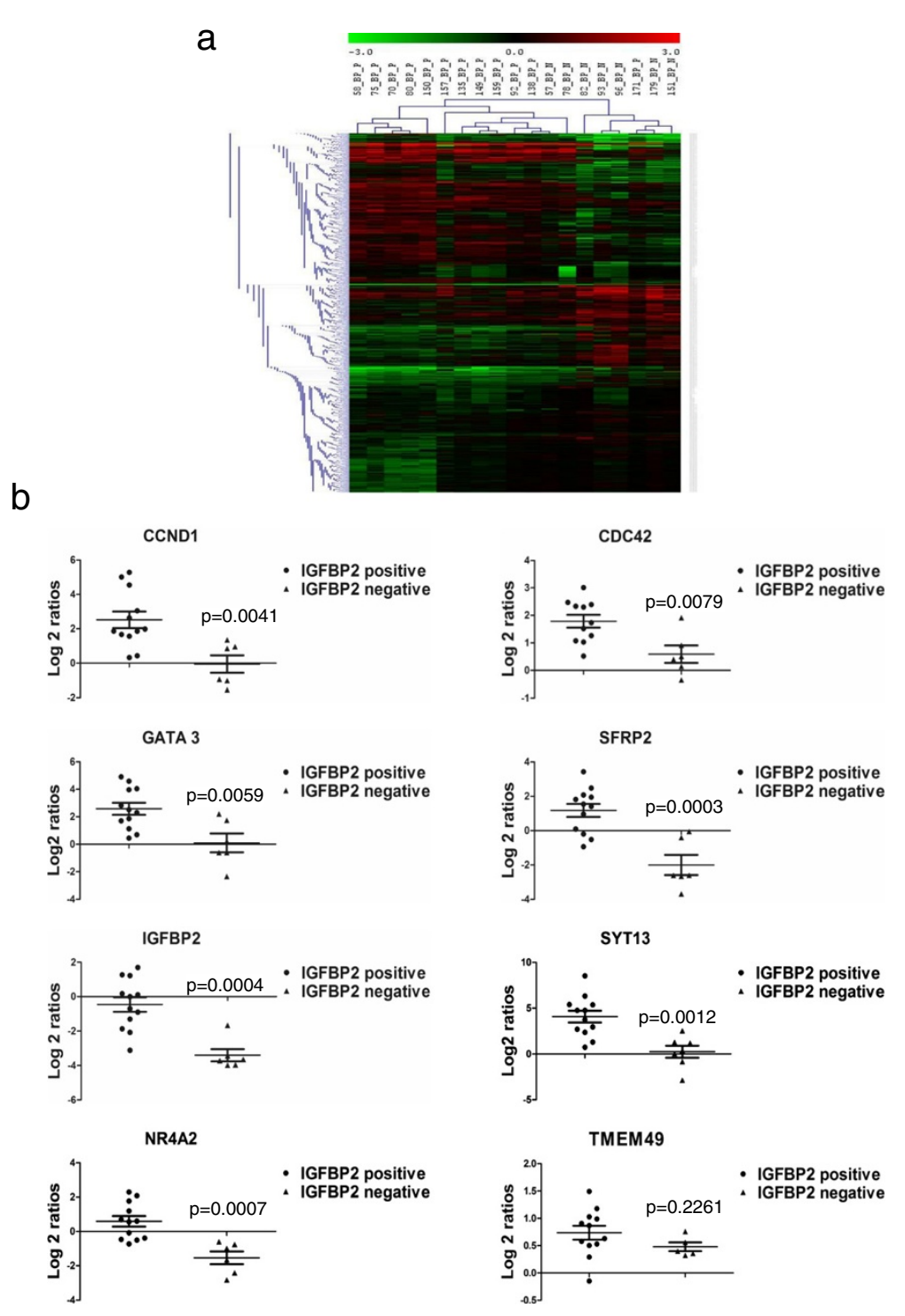

Figure 2 Differential expression of genes in IGFBP2 positive and IGFBP2 negative tumor samples compared to control tissues. a) Genes were clustered using MeV software. The dendrogram on the left shows different clusters of genes segregated according to the pattern of regulation. Red and green indicate high and low expression of genes respectively. Black indicates no regulation. b) Validation of selected genes. Scatter plots of differentially regulated genes in IGFBP2 positive and IGFBP2 negative tumors compared to the expression in normal tissues. Log 2-transformed gene expression ratios obtained from real-time quantitative PCR analysis normalized to TBP expression are plotted. Each dot represents a data derived from one sample.

that IGFBP2 acts through IGF1R and integrin pathways in the regulation of $\beta$-catenin. Although the mechanisms are not clear, recently Uzoh et al. demonstrated an increased proliferation of prostate cancer cells by IGFBP2 in an IGF1R dependent manner [20]. It is also known that IGF independent actions of IGFBP2 are mediated by the activation of integrin signaling through RGD motif present in the C-terminal region of IGFBP2 protein [30]. Role of integrin receptors in pro-tumorigenic action of tumor cells is well established $[42,43]$. Hence, it is conceivable that activation of integrin signaling by IGFBP2 leading to
FAK phosphorylation may be an important step in the activation of IGF1R by IGFBP2. In congruence with this, it has been reported that activated FAK phosphorylates and stabilizes IGF1R in mouse embryonic fibroblast [44]. Very recently, IGFBP2 in association with IGF1 was found to activate IGF1R in endothelial cells [45]. Taken together, regulation of Wnt pathway by IGFBP2 involves FAK and IGF1R in breast carcinogenesis. However, the mechanism (s) by which FAK and IGF1R signaling converge on the regulation of Wnt pathway by IGFBP2 needs further investigations. 
Table $\mathbf{5}$ List of top $\mathbf{5 0}$ common genes differentially regulated between IGFBP2 positive tumors and IGFBP2 knockdown clones

\begin{tabular}{|c|c|c|}
\hline Probe & Gene symbol & Accession no \\
\hline A_23_P119943 & IGFBP2 & NM_000597 \\
\hline A_23_P118392 & RASD1 & NM_016084 \\
\hline A_23_P211631 & FBLN1 & NM_006486 \\
\hline A_23_P53126 & LMO2 & NM_005574 \\
\hline A_23_P22433 & RP2 & NM_006915 \\
\hline A_23_P252306 & ID1 & NM_002165 \\
\hline A_24_P119745 & FN1 & NM_212482 \\
\hline A_23_P70307 & SMOC2 & NM_022138 \\
\hline A_23_P170986 & TMCC1 & NM_00101739 \\
\hline A_32_P140139 & F13A1 & NM_000129 \\
\hline A_23_P204850 & RB1 & NM_000321 \\
\hline A_32_P216004 & KCTD9 & AF130091 \\
\hline A_23_P83939 & SYAP1 & NM_032796 \\
\hline A_23_P259438 & DCK & NM_000788 \\
\hline A_32_P28284 & TPM4 & NM_003290 \\
\hline A_23_P42257 & IER3 & NM_003897 \\
\hline A_32_P152348 & HIST1H2BD & BQ683489 \\
\hline A_32_P66881 & TLR4 & NM_138554 \\
\hline A_32_P89709 & TPM1 & NM_00101800 \\
\hline A_23_P380848 & TXNL5 & NM_032731 \\
\hline A_24_P106297 & AMACR & NM_014324 \\
\hline A_23_P401055 & sox2 & NM_003106 \\
\hline A_23_P89799 & ACAA2 & NM_006111 \\
\hline A_23_P500799 & CASP6 & NM_001226 \\
\hline A_23_P134237 & RARRES2 & NM_002889 \\
\hline A_23_P113952 & AY227436 & AY227436 \\
\hline A_23_P88095 & TBC1D4 & NM_014832 \\
\hline A_23_P369343 & KLK8 & NM_144505 \\
\hline A_23_P371039 & NTSR1 & NM_002531 \\
\hline A_24_P844917 & AF222023 & AF222023 \\
\hline A_23_P90601 & STEAP3 & NM_182915 \\
\hline A_24_P57047 & DLL3 & NM_203486 \\
\hline A_23_P363426 & SRP46 & NM_032102 \\
\hline A_23_P204751 & ACCN2 & NM_020039 \\
\hline A_23_P11262 & F8A1 & NM_012151 \\
\hline A_23_P376591 & CLYBL & NM_206808 \\
\hline A_23_P80773 & SRPRB & NM_021203 \\
\hline A_23_P253221 & ARHGEF4 & NM_032995 \\
\hline A_24_P163237 & STOX2 & NM_020225 \\
\hline A_23_P8240 & FAM50B & NM_012135 \\
\hline A_23_P67529 & KCNN4 & NM_002250 \\
\hline A_24_P411186 & BCL11A & NM_022893 \\
\hline A_23_P358597 & POPDC3 & NM_022361 \\
\hline
\end{tabular}

Table 5 List of top $\mathbf{5 0}$ common genes differentially regulated between IGFBP2 positive tumors and IGFBP2 knockdown clones (Continued)

\begin{tabular}{lcc}
\hline A_23_P78518 & CEACAM19 & AK128234 \\
A_23_P91702 & EIF3S7 & NM_003753 \\
A_23_P415558 & ZNF212 & NM_012256 \\
A_24_P414269 & ALG3 & NM_005787 \\
A_23_P130764 & KCNJ14 & NM_170720 \\
A_24_P152635 & TXNDC14 & NM_015959 \\
A_23_P82478 & PUS7 & NM_019042 \\
\hline
\end{tabular}

Another important finding from our data is the correlation of IGFBP2 over expression with elevated $\beta$-catenin levels in breast tumors. In humans, breast tumors frequently exhibit elevated levels of IGFBP2 [12] and $\beta$-catenin, with higher expression levels of $\beta$-catenin correlating with a decreased patient survival [39]. In mice, over expression of an activated $\beta$-catenin leads to the development of mammary hyperplasia and adenocarcinomas [46]. These studies coupled with our data suggest that regulation of $\beta$-catenin could be an important step for the pro-tumorigenic actions of IGFBP2. Most significantly, when both IGFBP2 and $\beta$-catenin expression was correlated with the lymph node status of breast cancers, we found a significant association of IGFBP 2 and $\beta$-catenin staining with increased lymph node metastasis in comparison with tumors which did not show staining for either protein. Interestingly, in a previous report, expression of IGFBP2 and IGFBP5 were correlated with increased

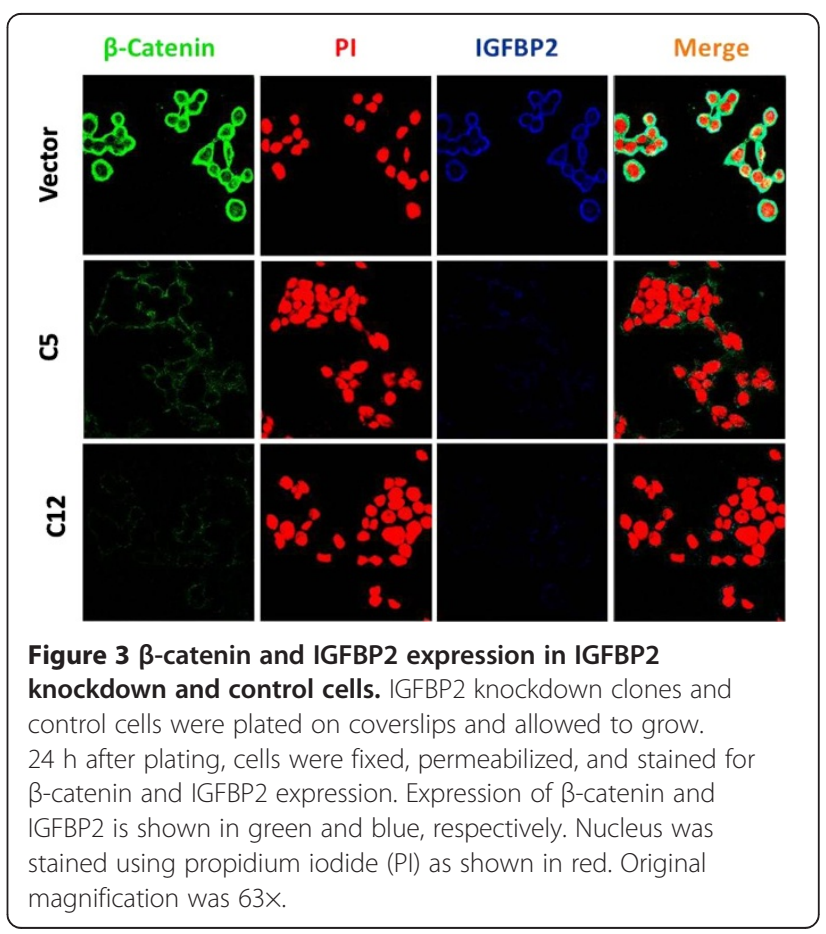




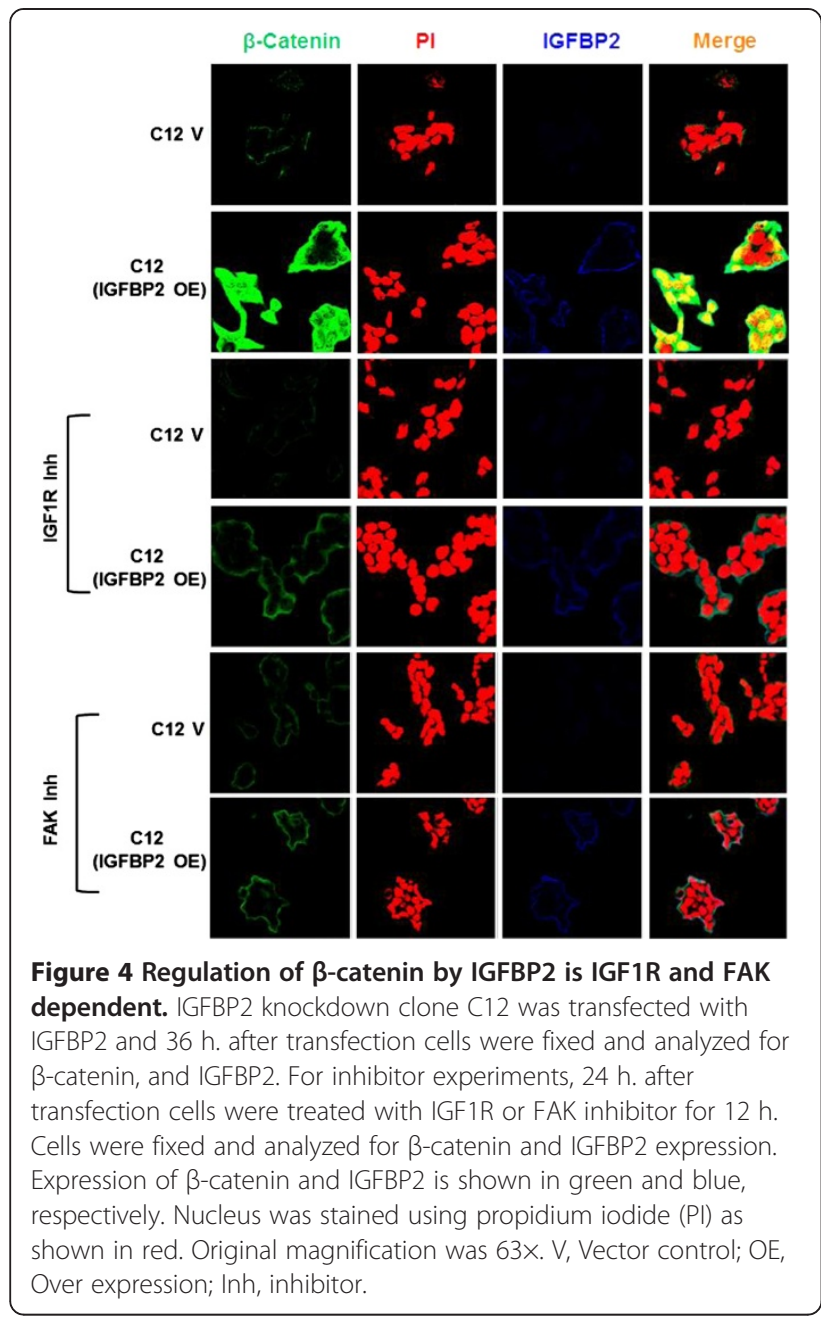

lymph node metastasis in T1 breast carcinoma. However our data shows a significant positive correlation of IGFBP2 and $\beta$-catenin in lymph node metastasis. Hence, evaluation of IGFBP2, IGFBP5 along with $\beta$-catenin may provide a stronger predictive value for the prognosis of breast cancer.

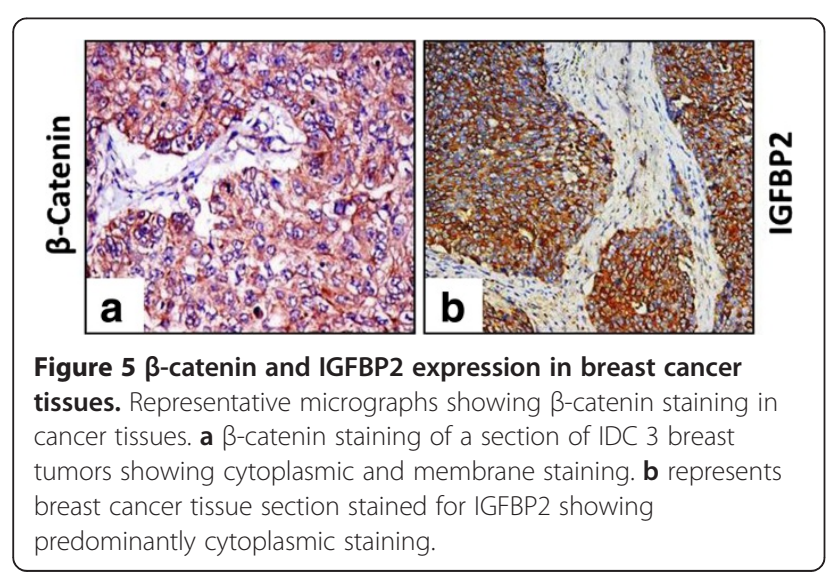

Table 6 IGFBP2 and $\beta$-catenin expression in breast cancer tissues

\begin{tabular}{|c|c|c|c|c|}
\hline S. No. & Case No. & IGFBP2 & $\beta$-catenin & Nodal status \\
\hline 1 & 160 & + & + & + \\
\hline 2 & 159 & + & + & - \\
\hline 3 & 157 & + & + & - \\
\hline 4 & 171 & + & + & + \\
\hline 5 & 150 & + & - & + \\
\hline 6 & 151 & - & + & + \\
\hline 7 & 180 & + & + & - \\
\hline 8 & 176 & + & + & + \\
\hline 9 & 174 & + & + & + \\
\hline 10 & 168 & + & + & + \\
\hline 11 & 165 & + & + & + \\
\hline 12 & 162 & + & + & - \\
\hline 13 & 149 & + & + & + \\
\hline 14 & 148 & + & + & + \\
\hline 15 & 143 & + & + & + \\
\hline 16 & 142 & + & + & + \\
\hline 17 & 140 & + & + & + \\
\hline 18 & 138 & + & + & - \\
\hline 19 & 137 & + & + & - \\
\hline 20 & 134 & + & + & + \\
\hline 21 & 133 & + & + & - \\
\hline 22 & 132 & + & + & - \\
\hline 23 & 130 & + & + & + \\
\hline 24 & 70 & + & + & + \\
\hline 25 & 94 & - & - & - \\
\hline 26 & 87 & + & + & + \\
\hline 27 & 49 & + & + & + \\
\hline 28 & 63 & + & + & + \\
\hline 29 & 117 & + & + & + \\
\hline 30 & 108 & - & + & + \\
\hline 31 & 96 & - & - & - \\
\hline 32 & 85 & - & + & - \\
\hline 33 & 77 & - & - & + \\
\hline 34 & 48 & - & + & + \\
\hline 35 & 57 & - & + & + \\
\hline 36 & 78 & - & + & + \\
\hline 37 & 30 & - & - & - \\
\hline 38 & 31 & - & - & - \\
\hline
\end{tabular}

\section{Conclusion}

This study highlights the pathways and genes regulated by IGFBP2 in breast cancer. Most importantly, this study reports regulation of $\beta$-catenin by IGFBP2 and their association in the lymph node metastasis. These findings 
are highly relevant in the prediction of breast cancer progression.

\section{Methods}

All the tissues for this study were collected after obtaining written informed consent from the patients. This study and the protocols were approved by the Institutional Ethics Committee of Kidwai Memorial Institute of Oncology, where the patients were treated.

\section{Cell culture and transfection}

BT474, a breast cancer cell-line was cultured in DMEM (Sigma-Aldrich, USA) with 10\% foetal bovine serum (FBS), 100 units $/ \mathrm{ml}$ penicillin and $100 \mu \mathrm{g} / \mathrm{ml}$ streptomycin, $2.5 \mu \mathrm{g} / \mathrm{ml}$ fungizone (Invitrogen Life Sciences, USA). All the cells were maintained at $37^{\circ} \mathrm{C}$ in a humid atmosphere with $5 \% \mathrm{CO}_{2}$. Transfections were performed using Lipofectamine 2000 (Invitrogen) based on the manufacturer's instructions. In brief, breast cancer cells were transfected with IGFBP2 shRNA expression vector (Origene, Cat no. TR316590) or empty vector (Origene, Cat no. TR20003) and $48 \mathrm{hrs}$ after transfection puromycin $(1 \mu \mathrm{g} / \mathrm{ml}$, Calbiochem) was added to the growth medium. Selection medium was replaced every 2-3 days until individual clones could be identified. After 3 weeks of selection, fourteen puromycin resistant clones of BT474 cells were isolated and expanded in the selective medium. Two clones (C5 and $\mathrm{C} 12)$ which showed significant down regulation of IGFBP2 expression were selected for further experiments Reversion of IGFBP2 expression in IGFBP2 knockdown cells was achieved by transfecting IGFBP2 cDNA sub cloned into pcDNA3.1 vector (Invitrogen). Pathway inhibitor treatments were performed using IGF1R inhibitor (PPP, $10 \mu \mathrm{M}$, Calbiochem Cat. No. 407247) and Focal Adhesion Kinase inhibitor (PP2, $10 \mu \mathrm{M}$, Calbiochem Cat. No. 529573).

\section{Immunoblot analysis}

For immunoblot analysis, cells were grown in growth medium till they achieved 50-70\% confluency, washed with serum free DMEM and cultured in serum free medium for another $48 \mathrm{~h}$. The spent medium was collected, concentrated using centrifugal filter units (Millipore, Amicon ultra-3 k) and equal amounts of protein as determined by the Bio-Rad DC protein assay (Bio-Rad, USA) were separated on $12.5-15 \%$ polyacrylamide gel and electrophoretically transferred onto PVDF membranes (Immobilin P, Millipore). Membranes were pre-incubated for $1 \mathrm{~h}$ with $5 \%$ non-fat dry milk (Fluka, Sigma-Aldrich) in Tris buffered-saline containing 0.1\% Tween 20 (TBST) and then were incubated overnight with primary antibody. (IGFBP2 C-18: sc-6001, Santa Cruz Biotechnology, Inc, CA). Membranes were washed thrice for $15 \mathrm{~min}$ in TBST at room temperature, incubated with appropriate horseradish-peroxidase conjugated IgG (Sigma-Aldrich) at a dilution of 1:2000 for $1 \mathrm{~h}$ at room temperature and the complex detected using Super Signal West Femto chemiluminescence (Pierce, Thermo Scientific), as per the manufacturer's instructions.

\section{RNA extraction and gene expression profiling}

Total RNA from frozen tumor tissues and tumor cells was extracted using the TRI reagent (Sigma-Aldrich) according to the manufacturer's protocol. The concentration of RNA was estimated by measuring the absorbance at $260 \mathrm{~nm}$ (Nano Drop ND-1000 spectrophotometer) and integrity was verified on a denaturing $1 \%$ MOPSformaldehyde agarose gel followed by ethidium bromide staining. For expression profiling, microarray experiments using whole genome human arrays $(4 \times 44 \mathrm{~K}$, Agilent) were used. The microarray hybridizations were performed as described before [47]. Microarray analysis was performed by R-Bioconductor (limma package) using subtract method for background correction [48]. Loess normalization was applied for dye bias and Quantile normalization was applied for spatial variation [49]. Linear model and empirical Bayes methods (limma) was used for assessing differentially regulated genes [50]. Benjamini Hochberg correction was applied for P value correction. Hierarchical cluster was done by Mev4.1 using Euclidean distance metric. The data was clustered by averaged linkage [51]. Adjusted p value cut-off was used as 0.05 for differentially regulated genes. Gene expression data are deposited into GEO (Clone arrays: GSE40682, Breast cancer tissue arrays: GSE40206).

\section{Real-time qPCR assay}

For RT-PCR, cDNA was synthesised from total RNA using the cDNA Archive kit (Applied Bio systems, USA). cDNA equivalent to $10 \mathrm{ng}$ of total RNA was used for all the PCR reactions using Dynamo SYBR green mix (Finnzymes, Finland) in ABI Prism 7900HT sequence detection system (Applied Bio systems, USA). The sequences of the primers are shown in Additional file 9: Table S5. The analysis has been done using SDS 2.1 software (Applied Bio systems, USA). For normalization of RT-PCR data, ribosomal protein L35a (RPL 35a) and TATA Binding Protein (TBP) were used for cells and tissues, respectively.

\section{Immunoflourescence}

Cells were grown on sterile cover-slips till they were about $50 \%$ confluent. The growth medium was discarded; cells were washed twice with chilled DPBS and were fixed in ice cold methanol for 10 minutes at $-20^{\circ} \mathrm{C}$. The fixed cells were then washed with DPBS thrice. For blocking nonspecific binding of the antibodies, the cells were incubated with $1 \%$ BSA in PBS for 60 min followed by overnight 
incubation with protein specific antibodies ( $\beta$-catenin, 1:50; IGFBP2, 1:25) in a humidified chamber at $4^{\circ} \mathrm{C}$. After the overnight incubation, the cells were washed thrice with PBS and incubated with the secondary antibody, 1:1500 dilution of alexa flur 488 (anti-rabbit, for $\beta$-catenin) and alexa flur 633 (anti-goat for IGFBP2) (Molecular probes, Invitrogen, USA) in PBS for 1 hour in dark. All steps thereafter were performed in the dark. After $1 \mathrm{~h}$, the cells were again washed thrice with PBS and counterstained with $33 \mu \mathrm{g} / \mathrm{ml}$ Propidium Iodide for 5 minutes and mounted in anti-fade solution on clean slides. The stained cells were visualized using a confocal microscope (LSM 510 Meta, Carl-Zeiss) and were photographed.

\section{Tissue samples and immunohistochemistry}

For histology, sections of breast tumor tissues were obtained from blocks archived in the Department of Pathology at the Kidwai Memorial Institute of Oncology (KMIO). The status of estrogen receptor (ER), progesterone receptor (PR), Her2/neu, and pathological data like tumor grade, size and lymph node status were obtained from the pathology records of the respective patients. Tissue sections $(5 \mu \mathrm{m})$ from the paraffin embedded tumor specimens were collected on silane-coated slides and immunohistochemistry for IGFBP2 and $\beta$-catenin was performed on 38 samples. Antigen retrieval was done by heat treatment of the deparaffinised sections in Citrate buffer (10 mM; pH 6.0). After the initial processing steps, sections were incubated overnight with respective primary antibodies - IGFBP2 (C-18: sc-6001, Santa Cruz Biotechnology, Inc, CA) and $\beta$-catenin (C 2206, SigmaAldrich), at $4^{\circ} \mathrm{C}$. This was followed by incubation with the linked streptavidin- biotinylated secondary antibody (Universal LSAB, DAKO, Denmark) for IGFBP2 and with supersensitive non-biotin horseradish peroxidase detection system (QD440-XAK, Biogenex) for $\beta$-catenin antibodies. 3, 3'-Diaminobenzidine (Sigma-Aldrich) was used as the chromogenic substrate.

\section{Evaluation of immunohistochemistry}

The scoring method used for IGFBP2 and $\beta$-catenin expression was based on semi quantitative scoring method as described before [52] where both intensity and percentage of cells with positive staining were counted and a combined score was given. The combined score was arrived by the multiplication product of both the scores. The scores are, (1) percentage of cells: no staining $=0 ; 10 \%$ or less of cells stained $=1 ; 11-50 \%$ of cells stained $=2$; and $50 \%$ or more of cells stained $=3$; (2) intensity: no staining $=0$, weak staining $=1$, moderate staining $=2$, and strong staining $=3$. Thus, the combined scores ranged from 0-9. Only scores from 4-9 were considered positive for staining.

\section{Statistical analysis}

Statistical significance for all experimental analyses (except microarray) was determined by Student's t-test or one-way analysis of variance GraphPad Prism 5.0 software (GraphPad Software, Inc., La Jolla, CA, USA). For correlation analysis Fisher's exact test was utilized.

\section{Additional files}

\begin{abstract}
Additional file 1: List of common probe between IGFBP2 Knockdown clones C5 and C12.

Additional file 2: Figure S1. Gene expression changes in IGFBP2 knockdown cells upon IGFBP2 over expression. Cells were plated and $24 \mathrm{~h}$ later transfected with pcDNA3.1-IGFBP2 and /or pCDNA3.1 vector $48 \mathrm{~h}$ post transfection, RNA was extracted and gene expression was analyzed by Semi quantitative RT-PCR analysis. Representative ethidium bromide gel shows the expression of genes regulated upon forced expression of IGFBP2 in a) clone C12 and $\mathbf{b}$ ) clone C5. Expression values were quantitated and the graph (right) represents fold change over control after normalization with the expression of RPL35A
\end{abstract}

Additional file 3: List of Differentially expressed probes between IGFBP2 positive and negative breast tumors.

Additional file 4: Figure S2. Validation of Wnt target genes in IGFBP2 positive and IGFBP2 negative tumors. Scatter plots of differentially regulated genes in tumor tissues compared to the expression in normal tissues. Log 2-transformed gene expression ratios obtained from real-time quantitative PCR analysis normalized to TBP expression are plotted. Each dot represents data derived from one sample.

Additional file 5: List of differentially regulated probes common between IGFBP2 knockdown clones and IGFBP2 positive/negative tumors.

Additional file 6: List of pathways associated with differentially regulated genes common between IGFBP2 knockdown clones and IGFBP2 positive/negative tumors.

Additional file 7: Figure S3. Regulation of $\beta$-catenin by IGFBP2 is IGF1R and FAK dependent. MDA-MB-231 cells were transfected with IGFBP2 and $36 \mathrm{~h}$. after transfection cells were fixed and analyzed for $\beta$ catenin and IGFBP2 protein. For inhibitor treatements, $24 \mathrm{~h}$. after transfection cells were treated with IGF1R or FAK inhibitor for $12 \mathrm{~h}$. Cells were fixed and analyzed for $\beta$-catenin and IGFBP2 expression. Expression of $\beta$-catenin and IGFBP2 is shown in green and blue, respectively. Nucleus was stained using propidium iodide (PI) as shown in red Original magnification was $63 \times$. V, Vector control; OE, Over expression; Inh, inhibitor.

Additional file 8: Figure S4. Comparison of IGFBP2 regulated genes in knock down cells with other available data sets. a) Venn diagram showing genes common between IGFBP2 over expressing glioma cells (GEO accession no. GSE35467) and IGFBP2 knock down breast cancer cells (Additional file 1: Table S1). b) Venn diagram showing genes common between RGE mutant IGFBP2 over expressing glioma cells (GEO accession no. GSE35467) and IGFBP2 knock down breast cancer cells (Table S1). OV, over expression; KD, knockdown; RGE, RGE mutant IGFBP2.

Additional file 9: List of primer sequences used for qPCR.

Competing interests

The authors declare that they have no competing interests.

Authors' contributions

PS planned, executed, interpreted experiments, manuscript writing; VRP, SP and $A B$ executed some experiments; NK did the microarray analysis; MVK and GM contributed in the planning and recruitment of patients and samples, clinical evaluation; PK, planned the experiments; manuscript writing and resources. All authors read and approved the final manuscript. 


\section{Acknowledgements}

We thank Ms. Humaira Tabbasum for sample collection, Mr. Shanmugam for IHC, Dr. Ravikiran Reddy, Ms. Meenakshi with confocal microscopy and Mr. Prasoon Agarwal for useful discussion on the analysis. Funding for this study was by a program support to PK by the Department of Biotechnology, Govt. of India. Infrastructure support to PK from the departments of a] Science and technology, b] biotechnology, c] UGC; Govt. of India are acknowledged.

\section{Author details}

'Department of Molecular Reproduction, Development and Genetics, Indian Institute of Science, Bangalore 560012, India. ${ }^{2}$ Departments of Pathology, $\mathrm{KMIO}$, Bangalore, India. ${ }^{3}$ Department of Surgery, KMIO, Bangalore, India.

Received: 9 October 2012 Accepted: 15 May 2013

Published: 16 June 2013

\section{References}

1. Hoeflich A, Reisinger R, Lahm H, Kiess W, Blum WF, Kolb HJ, Weber MM, Wolf E: Insulin-like growth factor-binding protein 2 in tumorigenesis: protector or promoter? Cancer Res 2001, 61:8601-8610.

2. Fuller GN, Rhee CH, Hess KR, Caskey LS, Wang R, Bruner JM, Yung WK, Zhang W: Reactivation of insulin-like growth factor binding protein 2 expression in glioblastoma multiforme: a revelation by parallel gene expression profiling. Cancer Res 1999, 59:4228-4232.

3. Wang H, Shen W, Huang H, Hu L, Ramdas L, Zhou YH, Liao WS, Fuller GN, Zhang W: Insulin-like growth factor binding protein 2 enhances glioblastoma invasion by activating invasion-enhancing genes. Cancer Res 2003, 63:4315-4321.

4. Sallinen SL, Sallinen PK, Haapasalo HK, Helin HJ, Helen PT, Schraml P, Kallioniemi OP, Kononen J: Identification of differentially expressed genes in human gliomas by DNA microarray and tissue chip techniques. Cancer Res 2000, 60:6617-6622.

5. Wang H, Rosen DG, Fuller GN, Zhang W, Liu J: Insulin-like growth factorbinding protein 2 and 5 are differentially regulated in ovarian cancer of different histologic types. Mod Pathol 2006, 19:1149-1156.

6. Flyvbjerg A, Mogensen O, Mogensen B, Nielsen OS: Elevated serum insulin-like growth factor-binding protein 2 (IGFBP-2) and decreased IGFBP-3 in epithelial ovarian cancer: correlation with cancer antigen 125 and tumor-associated trypsin inhibitor. J Clin Endocrinol Metab 1997, 82:2308-2313.

7. Chen R, Pan S, Yi EC, Donohoe S, Bronner MP, Potter JD, Goodlett DR, Aebersold R, Brentnall TA: Quantitative proteomic profiling of pancreatic cancer juice. Proteomics 2006, 6:3871-3879.

8. Zhang L, Huang W, Chen J, Zhou X, Lu Z, Zhou H: Expression of IGFBP2 in gastric carcinoma and relationship with clinicopathologic parameters and cell proliferation. Dig Dis Sci 2007, 52:248-253.

9. Kanety H, Madjar Y, Dagan Y, Levi J, Papa MZ, Pariente C, Goldwasser B, Karasik A: Serum insulin-like growth factor-binding protein-2 (IGFBP-2) is increased and IGFBP-3 is decreased in patients with prostate cancer: correlation with serum prostate-specific antigen. J Clin Endocrinol Metab 1993, 77:229-233.

10. Mishra L, Bass B, Ooi BS, Sidawy A, Korman L: Role of insulin-like growth factor-I (IGF-I) receptor, IGF-I, and IGF binding protein-2 in human colorectal cancers. Growth Horm IGF Res 1998, 8:473-479.

11. So Al, Levitt RJ, Eigl B, Fazli L, Muramaki M, Leung S, Cheang MC, Nielsen TO, Gleave M, Pollak M: Insulin-like growth factor binding protein-2 is a novel therapeutic target associated with breast cancer. Clin Cancer Res 2008, 14:6944-6954.

12. Busund LT, Richardsen E, Busund R, Ukkonen T, Bjornsen T, Busch C, Stalsberg H: Significant expression of IGFBP2 in breast cancer compared with benign lesions. J Clin Pathol 2005, 58:361-366.

13. Wex H, Vorwerk P, Mohnike K, Bretschneider D, Kluba U, Aumann V, Blum WF, Mittler U: Elevated serum levels of IGFBP-2 found in children suffering from acute leukaemia is accompanied by the occurrence of IGFBP-2 mRNA in the tumour clone. Br J Cancer 1998, 78:515-520

14. van der Laan BF, Freeman JL, Asa SL: Expression of growth factors and growth factor receptors in normal and tumorous human thyroid tissues. Thyroid 1995, 5:67-73.

15. McDonald KL, O'Sullivan MG, Parkinson JF, Shaw JM, Payne CA, Brewer JM, Young L, Reader DJ, Wheeler HT, Cook RJ, et al: IQGAP1 and IGFBP2: valuable biomarkers for determining prognosis in glioma patients. J Neuropathol Exp Neurol 2007, 66:405-417.
16. Lin Y, Jiang T, Zhou K, Xu L, Chen B, Li G, Qiu X, Zhang W, Song SW: Plasma IGFBP-2 levels predict clinical outcomes of patients with high-grade gliomas. Neuro Oncol 2009, 11:468-476.

17. Liou JM, Shun CT, Liang JT, Chiu HM, Chen MJ, Chen CC, Wang HP, Wu MS, Lin JT: Plasma insulin-like growth factor-binding protein-2 levels as diagnostic and prognostic biomarker of colorectal cancer. J Clin Endocrinol Metab 2010, 95:1717-1725.

18. Inman BA, Harel F, Audet JF, Meyer F, Douville P. Fradet Y, Lacombe L: Insulin-like growth factor binding protein 2: an androgen-dependent predictor of prostate cancer survival. Eur Urol 2005, 47:695-702.

19. Moore MG, Wetterau LA, Francis MJ, Peehl DM, Cohen P: Novel stimulatory role for insulin-like growth factor binding protein-2 in prostate cancer cells. Int J Cancer 2003, 105:14-19.

20. Uzoh CC, Holly JM, Biernacka KM, Persad RA, Bahl A, Gillatt D, Perks CM: Insulin-like growth factor-binding protein-2 promotes prostate cancer cell growth via IGF-dependent or -independent mechanisms and reduces the efficacy of docetaxel. Br J Cancer 2011, 104:1587-1593.

21. Hoeflich A, Yang Y, Huber S, Rascher W, Koepf G, Blum WF, Heinz-Erian P, Kolb HJ, Kiess W: Expression of IGFBP-2, -3, and -4 mRNA during differentiation of Caco-2 colon epithelial cells. Am J Physio/ 1996, 271:E922-E931.

22. Plymate SR, Tennant M, Birnbaum RS, Thrasher JB, Chatta G, Ware JL: The effect on the insulin-like growth factor system in human prostate epithelial cells of immortalization and transformation by simian virus-40 T antigen. J Clin Endocrinol Metab 1996, 81:3709-3716.

23. Birnbaum RS, Wiren KM: Changes in insulin-like growth factor-binding protein expression and secretion during the proliferation, differentiation, and mineralization of primary cultures of rat osteoblasts. Endocrinology 1994, 135:223-230.

24. Chakrabarty S, Kondratick L: Insulin-like growth factor binding protein-2 stimulates proliferation and activates multiple cascades of the mitogen-activated protein kinase pathways in NIH-OVCAR3 human epithelial ovarian cancer cells. Cancer Biol Ther 2006, 5:189-197.

25. Fukushima T, Tezuka T, Shimomura T, Nakano S, Kataoka H: Silencing of insulin-like growth factor-binding protein- 2 in human glioblastoma cells reduces both invasiveness and expression of progression-associated gene CD24. J Biol Chem 2007, 282:18634-18644.

26. Lee EJ, Mircean C, Shmulevich I, Wang H, Liu J, Niemisto A, Kavanagh JJ, Lee JH, Zhang W: Insulin-like growth factor binding protein 2 promotes ovarian cancer cell invasion. Mol Cancer 2005, 4:7

27. Miyake H, Hara I, Yamanaka K, Muramaki M, Gleave M, Eto H: Introduction of insulin-like growth factor binding protein-2 gene into human bladder cancer cells enhances their metastatic potential. Oncol Rep 2005, 13:341-345

28. Dunlap SM, Celestino J, Wang H, Jiang R, Holland EC, Fuller GN, Zhang W: Insulin-like growth factor binding protein 2 promotes glioma development and progression. Proc Natl Acad Sci USA 2007, 104:11736-11741.

29. Holmes KM, Annala M, Chua CY, Dunlap SM, Liu Y, Hugen N, Moore LM, Cogdell D, Hu L, Nykter M, et al: Insulin-like growth factor-binding protein 2-driven glioma progression is prevented by blocking a clinically significant integrin, integrin-linked kinase, and NF-kappaB network. Proc Natl Acad Sci USA 2012, 109:3475-3480.

30. Wang GK, Hu L, Fuller GN, Zhang W: An interaction between insulin-like growth factor-binding protein 2 (IGFBP2) and integrin alpha5 is essential for IGFBP2-induced cell mobility. J Biol Chem 2006, 281:14085-14091.

31. Wang H, Arun BK, Fuller GN, Zhang W, Middleton LP, Sahin AA: IGFBP2 and IGFBP5 overexpression correlates with the lymph node metastasis in T1 breast carcinomas. Breast J 2008, 14:261-267.

32. Frommer KW, Reichenmiller K, Schutt BS, Hoeflich A, Ranke MB, Dodt G, Elmlinger MW: IGF-independent effects of IGFBP-2 on the human breast cancer cell line Hs578T. J Mol Endocrinol 2006, 37:13-23.

33. Hoflich A, Lahm H, Blum W, Kolb H, Wolf E: Insulin-like growth factorbinding protein- 2 inhibits proliferation of human embryonic kidney fibroblasts and of IGF-responsive colon carcinoma cell lines. FEBS Lett 1998, 434:329-334.

34. Ueno K, Hirata H, Majid S, Tabatabai ZL, Hinoda Y, Dahiya R: IGFBP-4 activates the $\mathrm{Wnt} /$ beta-catenin signaling pathway and induces M-CAM expression in human renal cell carcinoma. Int J Cancer 2011, 129:2360-2369.

35. Reya T, Clevers H: Wnt signalling in stem cells and cancer. Nature 2005, 434:843-850. 
36. Nakopoulou L, Mylona E, Papadaki I, Kavantzas N, Giannopoulou I, Markaki S, Keramopoulos A: Study of phospho-beta-catenin subcellular distribution in invasive breast carcinomas in relation to their phenotype and the clinical outcome. Mod Pathol 2006, 19:556-563.

37. Gavert N, Ben-Ze'ev A: beta-Catenin signaling in biological control and cancer. J Cell Biochem 2007, 102:820-828.

38. Takahashi-Yanaga F, Kahn M: Targeting Wnt signaling: can we safely eradicate cancer stem cells? Clin Cancer Res 2010, 16:3153-3162.

39. Lin SY, Xia W, Wang JC, Kwong KY, Spohn B, Wen Y, Pestell RG, Hung MC: Beta-catenin, a novel prognostic marker for breast cancer: its roles in cyclin D1 expression and cancer progression. Proc Natl Acad Sci USA 2000, 97:4262-4266.

40. Brembeck FH, Rosario M, Birchmeier W: Balancing cell adhesion and Wnt signaling, the key role of beta-catenin. Curr Opin Genet Dev 2006, 16:51-59.

41. Valenta T, Hausmann G, Basler K: The many faces and functions of betacatenin. EMBO J 2012, 31:2714-2736.

42. Brooks PC, Klemke RL, Schon S, Lewis JM, Schwartz MA, Cheresh DA: Insulin-like growth factor receptor cooperates with integrin alpha $v$ beta 5 to promote tumor cell dissemination in vivo. J Clin Invest 1997, 99:1390-1398.

43. Kumar CC: Signaling by integrin receptors. Oncogene 1998, 17:1365-1373

44. Andersson S, D'Arcy P, Larsson O, Sehat B: Focal adhesion kinase (FAK) activates and stabilizes IGF-1 receptor. Biochem Biophys Res Commun 2009, 387:36-41.

45. Png K, Halberg N, Yoshida M, Tavazoie SF: A microRNA regulon that mediates endothelial recruitment and metastasis by cancer cells. Nature 2011, 481:190-194.

46. Tsukamoto AS, Grosschedl R, Guzman RC, Parslow T, Varmus HE: Expression of the int-1 gene in transgenic mice is associated with mammary gland hyperplasia and adenocarcinomas in male and female mice. Cell 1988, 55:619-625.

47. Khan I, Agarwal P, Thangjam GS, Radhesh R, Rao SG, Kondaiah P: Role of TGF-beta and BMP7 in the pathogenesis of oral submucous fibrosis. Growth Factors 2011, 29:119-127.

48. Ritchie ME, Silver J, Oshlack A, Holmes M, Diyagama D, Holloway A, Smyth GK: A comparison of background correction methods for two-colour microarrays. Bioinformatics 2007, 23:2700-2707.

49. Smyth GK, Speed T: Normalization of CDNA microarray data. Methods 2003, 31:265-273.

50. Smyth GK: Linear models and empirical bayes methods for assessing differential expression in microarray experiments. Stat Appl Genet Mol Biol 2004, 3:Article3.

51. Saeed Al, Sharov V, White J, Li J, Liang W, Bhagabati N, Braisted J, Klapa M, Currier T, Thiagarajan M, et al: TM4: a free, open-source system for microarray data management and analysis. Biotechniques 2003, 34:374-378.

52. Hernandez JM, Farma JM, Coppola D, Hakam A, Fulp WJ, Chen DT, Siegel EM, Yeatman TJ, Shibata D: Expression of the antiapoptotic protein survivin in colon cancer. Clin Colorectal Cancer 2011, 10:188-193.

doi:10.1186/1476-4598-12-63

Cite this article as: Sehgal et al:: Regulation of protumorigenic pathways by Insulin like growth factor binding protein2 and its association along with $\beta$-catenin in breast cancer lymph node metastasis. Molecular Cancer 2013 12:63.

\section{Submit your next manuscript to BioMed Central and take full advantage of:}

- Convenient online submission

- Thorough peer review

- No space constraints or color figure charges

- Immediate publication on acceptance

- Inclusion in PubMed, CAS, Scopus and Google Scholar

- Research which is freely available for redistribution 